the Directors of the South-Fastern Railway Company. To be turned out of their old domain, and to be left to tind seven acres in Londun wherever they could, and, worse than that, to be exposed to incessant petitions, remonstrances, and threats from the parishes of Southwark, to an infinite amount of all sorts of advice, and finally to be handed over to the tender mercies of the Metropolitan Bourd of Works-all this combined can hardly conduce to a state of benevolence towards its authors. Perhaps, indeed, the consideration may explain the otherwise unaccountable fancy of the governors for removing a London charity entirely away from London. They may have wanted to get as far away from the South-Eastern Railway as possible.

"There is not much to complain of in the site they have at last determined on. In some respects it is even better than Bethlehem. We are harily able to judge of it fairly yet, for, in fact, it hardly exists. We associnte the side of the river opposite the Houses of Parliament with filthy mud-banks and smells the reverse of wholesome; and it must be confessed that, as the Thames exists at present, its banks do not seem very eligible sites for a hospital. But it must be remembered that we are steadily and surely freeing the river from its impurities, and when that work is accomplished its banks will enjoy a greater volume of pure air than can be obtained in any other site. The contract with the Metropolitan Board of Works stipulates that the land shall be reclaimed and embanked by the 31 st of December, 1865 ; it will he some time after that before the new hospital is built, and by the time it can be occupied the new drainage scheme ought to be completed, and the embankment of the river considerably advanced. When those two works are successfully carried out there will be few sites so healthy or so pleasant as the river side. The river affords, too, a cheap and easy means of access to the hospital, and the site of the new hospital will be as complete a reproduction as possible of that of the old St. Thomas's at London Bridge."-Times, Nov. 24.

\title{
The Charity Commissioners and Bethlehem Hospital.
}

Yesterday Mr. Martin, Inspector of Charities, commenced an official inquiry, in the committee-room of Bridewell Hospital, into the foundations, endowments, and objects of Bethlehem and Bridewell Hospitals. The inspector stated that he came there under an order of the Charity Commissioners of England and Wales, to make an official inquiry, not that they had any reason to suspeet that anything was wrong, but in the simple performance of the duties of their office. Although he beld an order to inquire into Bridewell as well as Bethlehem, he should at present confine his inquiry to Bethlehem Hospital. He had a very strong opinion as to the policy of releasing their Lincolnshire estate, which was a special trust for the permanent maintenance of incurable lunatics, which was now rendered altogether unnecessary by the establishment of lunatic asylums in every county. The admission of so many incurable patients into Bethlehem Hospital not only created a very great expense beyond the funds obtained from their Lincoln. shire estate, but was a bar to the admission of some 1100 or 1200 patients annually. He should collect evidence on that point. Another question upon which he had not yet formed an opinion was the policy of removing Bethlehem Hospital into the country. Upon that he should take the evidence of the governors, the resident physician, and other medical officers. After some remarks upon the question of charities generally, and the frequent misuse of several of them, the public portion of the inquiry was udjourned sine die. In the mean time the inspector will be engaged in 
examining the books and accounts of Bethlehem Hospital.-The Daily Telegraph, November 27.

\section{One of the Results of the Restraint System in France.}

We commend the following paragraph which has been going the round of the English papers to the notice of M. Renaudin.*

A melancholy catastrophe has just taken place in the Aisne, where a great part of the Lunatic Asylum of Montreuil-sous-Laon has been destroyed by fire and six of its inmates burnt to death. The establishment was full of lunatics of both sexes. Among them was a young man about 25 years of age, who was usually kept in a separate cell and with a strait waistcoat on. On the day before the fire he was visited by some of his relatives, who requested the director to release him from that confinement, and as he then appeared more tranquil it was done. The following morning he by some means or other got possession of a chemical match, and at night set fire to his bed, which was soon burnt, and the fire afterwards caught the woodwork with which all the cells of the violent lunatics are lined, and next burnt through the ceiling to the roof above. Once getting vent, the flames rapidly extended right and left, and spread alarm throughout the place. The keepers and others then rushed to the different cells to get out the inmates, which was a work of great difficulty, as many of them were strapped down to their beds, and after they were set free they had to be carried out by main force. The task was at last accomplished, and the guardians and others were congratulating themselves that no lives had been lost, when, on making another round among the cells, they found that six of the women had rushed back unobserved into the flames, where they met a horrible death. As for the madman who had caused the catastrophe, he was afterwards found running about in the garden singing and appearing highly delighted with what he had done.

\section{General Statistics of Asylums for the Insane.}

In one of our former numbers (April 1863, page 149), we noticed Dr. A. Erlenmyer's synopsis and statistical account of the asylums of Europe.

We find now in a popular German journal called the 'Irren Freund' (April and May, 1863), a critique-by one of the editors, Dr. Brosius, - on Dr. A. Erlenmyer's statistical tables of Switzerland, which country Dr. Brosius visited a short time ago for this express purpose.

Dr. Brosius found in almost every paragraph of Dr. A. Erlenmyer's tables of Switzerland grave mistakes and errors.

It is a striking example how inaccurate and consequently useless such statistical labours finally prove to be.

We take this opportunity to inform our readers that similar reasons have induced Doctor Mundy to abstain from continuing the publication of the statistical tables which he began in the January number (1863), of this Journal.

- See 'Journal of Mental Science,' July, 1863, p. 296. M. Renaudin "On the English County Asylums for the Insane" 